\title{
The Effect and Mechanism of Celecoxib in Hypoxia-Induced Survivin Up-Regulation in HUVECs
}

\author{
Ning-ning Liu Ning Zhao Na Cai \\ The Department of Ophthalmology, the First Affiliated Hospital of China Medical University, Shenyang, \\ Liaoning, China
}

\section{Key Words}

Cyclooxygenase-2 2 Survivin $\bullet$ Hypoxia inducible factor- $1 \alpha \cdot$ Human umbilical vein endothelial cells

\begin{abstract}
Background/Aims: To investigate the roles of hypoxia-inducible factor $1 \alpha$ (HIF-1 $\alpha$ ), cyclooxygenase-2 (Cox-2) and its product, Prostaglandin E2 $\left(\mathrm{PGE}_{2}\right)$, in the mechanisms underlying hypoxia-induced survivin expression in human umbilical vein endothelial cells (HUVECs) and to examine the effect of celecoxib, a selective Cox-2 inhibitor, on survivin expression. Methods: HUVECs were exposed to a normal $\left(95 \% \mathrm{O}_{2}\right)$ or hypoxic $\left(3 \% \mathrm{O}_{2}\right)$ environment for $24 \mathrm{hrs}$. We observed the localized expression of survivin, Cox-2 and HIF-1 $\alpha$ in HUVECs using immunocytochemistry and detected the inhibitory effects of celecoxib on the growth of HUVECs using an MTT assay. mRNA and protein levels of Cox-2, HIF- $1 \alpha$ and survivin were determined by real-time PCR and Western blot analysis under hypoxic conditions for 0 , 6,12 , or $24 \mathrm{hrs}$. The time course changes of HIF-1 $1 \alpha$ and survivin protein expression induced by cobalt chloride $\left(\mathrm{CoCl}_{2}\right)$ were studied using Western blot analysis. We then treated HUVECs under hypoxia for 24 hrs with celecoxib (a Cox-2 selective inhibitor), genistein (a HIF-1 $\alpha$ inhibitor) or exogenous $\mathrm{PGE}_{2}$ to further investigate the changes in hypoxia-induced survivin expression. Results: Following 24 hrs of hypoxic treatment, cells exhibited strongly positive survivin, HIF$1 \alpha$ and Cox-2 cytoplasmic staining. Celecoxib $(65 \mu \mathrm{M})$ effectively inhibited cell proliferation under hypoxic conditions. The protein and mRNA levels of Cox-2, HIF-1 $\alpha$ and survivin were increased under hypoxia. The patterns of HIF-1 $\alpha$ and survivin expression induced by $\mathrm{CoCl}_{2}$ were similar to those induced by exposure to hypoxia. Genistein partially blocked survivin expression. Celecoxib reversed the hypoxia-induced survivin expression, whereas the addition of $\mathrm{PGE}_{2}$ partially restored this effect. Conclusions: Hypoxia-induced survivin expression in HUVECs may be mediated by dual interdependent mechanisms directly involving HIF-1 $\alpha$ and indirectly involving the Cox-2/PGE 2 pathways. Celecoxib may offset hypoxia-induced survivin expression.
\end{abstract}




\section{Introduction}

Pathological angiogenesis, or neovascularization, is one of the vital characteristics in tumor development and hypoxia-induced ocular diseases [1]. Hypoxia is a primary etiological factor causing neovascularization [2]. One of the critical pathways regulated by hypoxia is the hypoxia inducible factor $1 \alpha(\mathrm{HIF}-1 \alpha)$ pathway. Under hypoxic conditions, it has been found that HIF-1 $\alpha$ over-expression stimulates the transcription of its downstream target genes involved in neovascularization, promoting glucose metabolism and cell proliferation. The inhibition of HIF-1 $\alpha$ activity distinctly slows tumor growth and activates radiochemotherapic sensitivity in tumor cells [3, 4].

Survivin is a novel member of the inhibitor of apoptosis protein (IAP) family, which regulates apoptosis and the cell cycle. Survivin expression can be induced by hypoxia [5], correlates strongly with cell proliferation, and promotes angiogenesis [6]. Increasing evidence suggests that survivin is highly expressed in most human tumors and is closely associated with tumor progression, tumor recurrence, chemotherapy resistance and poor prognosis [7]. HIF- $1 \alpha$ appears to be involved in regulating survivin expression in multiple tumors and hypoxia-induced cancer cell lines $[8,9]$. Our previous study also found that both molecules are involved in retinal neovascularization, and HIF- $1 \alpha$ may be a major transcription factor in regulating survivin expression in retinal neovascularization [10].

Cyclooxygenase-2 (Cox-2), an isoform of cyclooxygenase, converts arachidonic acid into various prostaglandins (in particular prostaglandin $\mathrm{E} 2, \mathrm{PGE}_{2}$ ) in response to hypoxia and is associated with neovascularization, tumor growth and cellular migration [11]. Recently, Bai et al. [12] revealed that $\mathrm{PGE}_{2}$ plays an important role in the regulation of survivin expression in hepatocellular carcinoma cells. Our preliminary experiments found that both Cox-2 and survivin expression were increased in a mouse model of hypoxia-induced retinopathy $[10,13]$. Accordingly, we hypothesized that Cox-2 may also play a key role in survivin upregulation. Additionally, our preliminary experiments demonstrated that rofexocib, a highly selective Cox-2 inhibitor, attenuated retinal angiogenesis by inhibiting Cox-2 expression [13]. We hypothesized that there may be some links among the pathways through which HIF- $1 \alpha$, survivin and Cox- 2 are regulated in hypoxia-induced retinal neovascularization. As endothelial cells (ECs) are the main cell types involved in neovascularization [14], we sought to use an in vitro model of human umbilical vein endothelial cells (HUVECs) to explore the roles of HIF1- $\alpha$, Cox- 2 and its product, $\mathrm{PGE}_{2}$, in the mechanisms underlying hypoxia-induced survivin expression. We also aimed to investigate the effect of celecoxib, a safer selective Cox2 inhibitor than rofexocib, on hypoxia-induced survivin up-regulation in HUVECs.

\section{Materials and Methods}

Cell culture and experimental protocols

HUVECs (SIBS, CAS. Code: ECV304) were maintained in RPMI-1640 medium (GIBCO, USA) supplemented with $10 \%$ fetal calf serum, $100 \mathrm{U} / \mathrm{ml}$ penicillin, and $100 \mathrm{mg} / \mathrm{ml}$ streptomycin. All cells were cultured in $25 \mathrm{~cm}^{2}$ flasks and maintained in an incubator supplied with 95\% air, 5\% $\mathrm{CO}_{2}$ and $100 \%$ humidity at $37^{\circ} \mathrm{C}$. Fresh RPMI-1640 medium was changed every three days. Cells were washed twice with phosphatebuffered solution (PBS) and detached with $0.25 \%$ trypsin plus $0.05 \%$ ethylenediaminetetraacetic acid (EDTA) (Sigma-Aldrich, St. Louis, MO, USA) for passage. Passage 3 - 5 HUVECs were used in our experiments. With $80 \%$ confluence, HUVECs were serum-starved for $16 \mathrm{hrs}$ and then exposed to an environment of 3\% $\mathrm{O}_{2}, 5 \% \mathrm{CO}_{2}, 92 \% \mathrm{~N}_{2}$, at $37^{\circ} \mathrm{C}$ for 6,12 and $24 \mathrm{hrs}$. In other experiments, a chemical hypoxia model was established by adding $125 \mu \mathrm{M} \mathrm{CoCl}_{2}$ in HUVEC culture medium for 6, 12, or 24 hrs to mimic a hypoxic environment.

To investigate the effect of celecoxib on HUVEC proliferation, 15, 30, 65 or $100 \mu \mathrm{M}$ of celecoxib was added separately in the culture medium of serum-starved HUVECs for $4 \mathrm{hrs}$, and the cells were then exposed to hypoxia. In some experiments, $5 \mu \mathrm{M} \mathrm{PGE}_{2}$ was added to hypoxic-treated HUVECs for $24 \mathrm{hrs}$ in the presence of $65 \mu \mathrm{M}$ of celecoxib. To study the effect of HIF-1 $\alpha$ on survivin expression, HUVECs were pre-incubated 
with different concentrations $(0,50,100$ or $200 \mu \mathrm{M})$ of genistein, an inhibitor of HIF- $1 \alpha$ for 30 min before hypoxic exposure. Data from cells cultured under normoxic conditions were regarded as the baseline and were defined as hypoxia $0 \mathrm{hr}$. All experiments were repeated three times.

\section{Immunocytochemistry method}

$1 \times 10^{4}$ HUVECs with or without hypoxic treatment were seeded on coverslips placed in wells of six-well plates. The experimental protocol followed the instruction of the strep avidin-biotin complex method (Beijing Zhongshan Golden Bridge Biotechnology, Beijing, China). Briefly, HUVECs grown on glass coverslips were fixed with $4 \%$ paraformaldehyde for $20-30$ min, washed with PBS three times and air-dried at $4^{\circ} \mathrm{C}$. HUVECs were then treated with $3 \%$ hydrogen peroxide for $15 \mathrm{~min}$ at room temperature to block intrinsic peroxidase and washed with PBS three times. Fixed cells were incubated for $1 \mathrm{hr}$ at $37^{\circ} \mathrm{C}$ with the following primary antibodies (rabbit polyclonal antibodies, Santa Cruz, CA): Cox-2 (1:200 in PBS), HIF-1 $\alpha$ (1:200 in PBS) and survivin (1:100 in PBS). A negative control was incubated with PBS instead of primary antibody. Subsequently, cells were washed in PBS and incubated with biotin-conjugated goat anti-rabbit IgG (Santa Cruz, CA, USA) for $1 \mathrm{hr}$ at $37^{\circ} \mathrm{C}$ before they were incubated with horseradish peroxidase labeled streptavidin for $20 \mathrm{~min}$ at $37^{\circ} \mathrm{C}$ and developed using the chromogen 3,3'-diaminobenzidine (DAB; Beijing Zhongshan-Golden Bridge Biotechnology). Five independent experiments were performed. The coverslips were mounted and analyzed using microscopy (Nikon, Japan). Protein expression was semi-quantitatively evaluated according to the immunohistochemical score (IHS) [15]: 0 , no labeling; $1+$, mild labeling $(<30 \%$ positive cells); $2+$, moderate labeling (30-70\% positive cells) and $3+$, intense labeling ( $>70 \%$ positive cells).

\section{3-(4, 5-dimethylthazol-2-yl)-2, 5-diphenyltetrazolium bromide (MTT) assay}

An MTT assay was performed to examine the effect of celecoxib on the growth of HUVECs under normoxic or hypoxic conditions. $\mathrm{IC}_{50}$ values of celecoxib were obtained through dose-response curves. Cells were seeded at $5 \times 10^{3} /$ well in 96 -well plates continuously cultured for $24 \mathrm{hrs}$ under normoxic conditions. The cells were incubated with medium plus 15, 30, 65 or $100 \mu \mathrm{M}$ of celecoxib under hypoxic conditions for $24 \mathrm{hrs}$. The cells within these groups were supplemented with $20 \mu \mathrm{mol} / \mathrm{dL}$ MTT and incubated for another $4 \mathrm{hrs}$. The culture medium was then removed and $150 \mu \mathrm{l} /$ well dimethyl sulfoxide (DMSO) was added, which enabled MTT crystals to completely dissolve. An enzyme-linked immunoassay analyzer determined the absorbance of each well at $490 \mathrm{~nm}$ (A490). The inhibition rates of cell growth were calculated based on a published formula [16].

\section{Quantitative real-time RT-PCR}

Total RNA under hypoxic treatment for $0,6,12$ or $24 \mathrm{hrs}$ was extracted with Trizol reagent (Life Technologies, Carlsbad, USA) according to the manufacturer's instruction. The reverse transcription reaction was performed using the PrimeScript RT reagent Kit (TaKaRa, Dalian, China). The PCR reaction was performed using the SYBR Green Kit (Toyobo, Shang Hai, China) in a thermal cycler (Applied BiosystemsStepOne, America). $\beta$-actin was used as an internal control. The following primers were used: survivin: forward 5'AGC CCT TTC TCA AGG ACC AC3'; reverse 5'CAG CTC CTT GAA GCA GAA GAA 3'; Cox-2: forward 5'TGA GCA TCT ACG GTT TGCTC3'; reverse 5'TGC TTG TCT GGA ACA ACTGC 3': HIF- $1 \alpha$ : forward 5'TCA TCC AAG AAG CCC TAACG3'; reverse 5'TCG CTT TCT CTG AGC ATT CTGC3'; $\beta$-actin: forward 5'ATA GCA CAG CCT GGA TAG CAA CGTAC3'; reverse 5'CAC CTT CTA CAA TGA GCT GCG TGTG3'.

The PCR reactions consisted of 6 min at $95^{\circ} \mathrm{C}, 40$ cycles at $95^{\circ} \mathrm{C}$ for 20 seconds, $60^{\circ} \mathrm{C}$ for 10 seconds and $72^{\circ} \mathrm{C}$ for 20 seconds.

\section{Western blot analysis}

Cells cultured under hypoxic conditions for 0, 6, 12 or 24 hrs were collected and lysed in RIPA buffer (Cell Signaling Technology, containing $50 \mathrm{mM}$ Tris- $\mathrm{HCl} \mathrm{pH}$ 7.5, $150 \mathrm{mM} \mathrm{NaCl}, 1 \%$ Nonidet P-40, 0.5\% deoxycholate, and $0.1 \%$ SDS) and incubated on ice for $30 \mathrm{~min}$. The protein concentration was measured using the Bradford method with reagents from Bio-Rad (Hercules, CA, USA). Cell extracts (50 $\mu \mathrm{g}$ of protein) were subjected to $10 \%$ SDS-PAGE and transferred to a nitrocellulose membrane (Hybond C, Amersham, and Piscataway New Jersey, USA). Membranes were blocked with $5 \%$ (w/v) nonfat milk and probed with rabbitanti human polyclonal antibodies (Cox-2, 1:300; HIF-1 $\alpha$, 1:200; survivin, 1:400) (Santa Cruz, CA, USA) and a mouse anti-human $\beta$-actin monoclonal antibody $(1: 400)$ at $4^{\circ} \mathrm{C}$ overnight. The membranes were incubated 


\section{Cellular Physiology Cell Physiol Biochem 2015;37:991-1001 \begin{tabular}{ll|l} 
and Biochemistry & $\begin{array}{l}\text { DOI: 10.1159/000430225 } \\
\text { Published online: September 23, } 2015\end{array}$ & $\begin{array}{l}\text { O 2015 S. Karger AG, Basel } \\
\text { www.karger.com/cpb }\end{array}$ \\
\cline { 2 - 3 }
\end{tabular}}

Liu et al.: Celecoxib Regulates the Hypoxia Induced Survivn Expression

with goat anti-rabbit alkaline phosphatase-labeled antibody and horse anti-mouse IgG antibody (Santa Cruz, CA, USA). All experiments were performed in triplicate. The specific protein bands were visualized with enhanced chemiluminescence (ECL, Amersham-Pharmacia Biotech, Beijing, China) according to the manufacturer's instruction. Autoradiograms were quantified by densitometry. Relative protein levels were compared among the samples using the $\beta$-actin densities as an internal control.

\section{Chemical hypoxia model}

To assess whether hypoxia-induced HIF-1 $\alpha$ up-regulation alone may result in elevated expression in survivin, a chemical hypoxia model was developed to stimulate HIF-1 $\alpha$ up-regulation. A chemically induced hypoxic environment was created by exposing cells to $125 \mu \mathrm{M}$ cobalt chloride $\left(\mathrm{CoCl}_{2}\right.$, Sigma-Aldrich, Dorset, UK) for 6, 12 or $24 \mathrm{hrs}$. The levels of HIF-1 $\alpha$ and survivin were determined by Western blot analysis.

$P G E_{2}$ assay

Increasing evidence indicates that $\mathrm{PGE}_{2}$ regulates the expression of survivin in some cancer cells [17]. However the reports on survivin expression in HUVECs are rare. To investigate the levels of PGE 2 protein secreted by HUVECs exposed to normoxia, hypoxia alone or hypoxia plus $65 \mu \mathrm{M}$ celecoxib for $24 \mathrm{hrs}$, the supernatants were collected for analysis using a PGE 2 ELISA kit (R\&D Systems, Inc., Minneapolis, MN, USA) according to the manufacturer's protocol.

\section{Effects HIF-1 $\alpha$ inhibition on survivin expression}

HIF-1 $\alpha$ is involved in the regulation of survivin expression under hypoxic conditions [18]. Genistein has been found to attenuate HIF-1 $\alpha$ gene expression $[19,20]$ and was therefore applied as a HIF-1 $\alpha$ inhibitor as described in another study [21] to explore whether hypoxia-induced HIF-1 $\alpha$ is the only pathway that induces survivin expression. HUVECs were cultured under hypoxic conditions for $24 \mathrm{hrs}$ in the presence of 50,100 or $200 \mu \mathrm{M}$ genistein. The cells were collected, and the levels of HIF-1 $\alpha$ and survivin were determined by Western blot.

\section{Effects of celecoxib on protein expression of Cox-2 and survivin}

Cox-2 was reported to be involved in survivin regulation in human cancer cells [22], but its effects in HUVECs have not been reported in detail. We used celecoxib (Sigma, USA) to inhibit Cox-2 expression. Our preliminary tests showed that increased survivin expression was most prominent 24 hrs after hypoxic treatment, so this time point was chosen in the present study. Celecoxib was added to the HUVEC medium for 4 hrs before hypoxic treatment. The minimum effective concentration (MEC) of inhibitor necessary for significant inhibition of survivin protein expression was determined by a concentration gradient test in which celecoxib was used at final concentrations of 15, 30, 65 or $100 \mu \mathrm{M}$. HUVECs were exposed to hypoxia for 24 hrs in the presence of the indicted concentrations of celecoxib and then collected for survivin and Cox-2 assays.

Effects of exogenous $P G E_{2}$ on hypoxia-induced survivin expression in the presence of celecoxib

Cox-2-mediated production of $\mathrm{PGE}_{2}$ is involved in cancer cell growth [23], and survivin is also implicated in cell growth in many cancers [24]. Interestingly, survivin and Cox-2 are often co-expressed [25]. Selective Cox-2 inhibitors have been reported to induce cell apoptosis by decreasing survivin expression [26]. Survivin protein stabilization is also modulated by $\mathrm{PGE}_{2}$ [27], as treatment with $\mathrm{PGE}_{2}$ significantly increases survivin expression in human cancer cell lines [28], but the mechanisms involved in $\mathrm{PGE}_{2}$ mediated survivin expression in HUVECs remain unclear. To exclude the hypothesis that exogenous $\mathrm{PGE}_{2}$ could be a confounding factor contributing to the effects of Cox-2 on hypoxia-induced survivin expression in HUVECs, $5 \mu \mathrm{M}$ of $\mathrm{PGE}_{2}$ was added to HUVECs exposed to hypoxia for $24 \mathrm{hrs}$ in the presence of $65 \mu \mathrm{M}$ of celecoxib. The cells were then collected for survivin assays by Western blot.

\section{Statistical analysis}

Statistical analysis was performed using SPSS10.0 software. One-way analysis of variance (ANOVA) was used to evaluate the differences among the groups. A p-value $<0.05$ was considered to be statistically significant. 


\section{Results}

\section{Immunocytochemical staining}

Under normoxic conditions, there was no expression or weak expression in HIF- $1 \alpha$, Cox2 and survivin. After 24 hrs of hypoxic treatment, expression of the three proteins markedly increased in the cytoplasm (nucleus) (Fig. 1).

\section{Effect of celecoxib on HUVEC proliferation}

The cell proliferation of HUVECs treated with 30,65 or $100 \mu \mathrm{M}$ celecoxib was decreased compared to cells treated with $15 \mu \mathrm{M}$ celecoxib $(\mathrm{p}<0.05)$. When treated with $65 \mu \mathrm{M}$ celecoxib, cell proliferation under hypoxic conditions was decreased compared with that observed under normoxic conditions ( $\mathrm{p}<0.01$ ) (Fig. 2).

Hypoxia increases mRNA and protein expression of HIF-1 $\alpha$, Cox-2 and survivin

In normoxia, mRNA and protein expression of HIF-1 $\alpha$ and survivin were hardly detectable in HUVECs. The mRNA (Fig. 3A) and protein levels (Fig. 3B \& C) of Cox-2, HIF-1 $\alpha$ and survivin were significantly elevated by hypoxia in a manner dependent on the length of time of exposure. Cox- 2 expression increased at $6 \mathrm{hrs}$ and peaked at $12 \mathrm{hrs}$. HIF-1 $\alpha$ and survivin expression peaked at $12 \mathrm{hrs}$ and $24 \mathrm{hrs}$, respectively, with the expression of HIF-1 $\alpha$ maintained at $24 \mathrm{hrs}$.

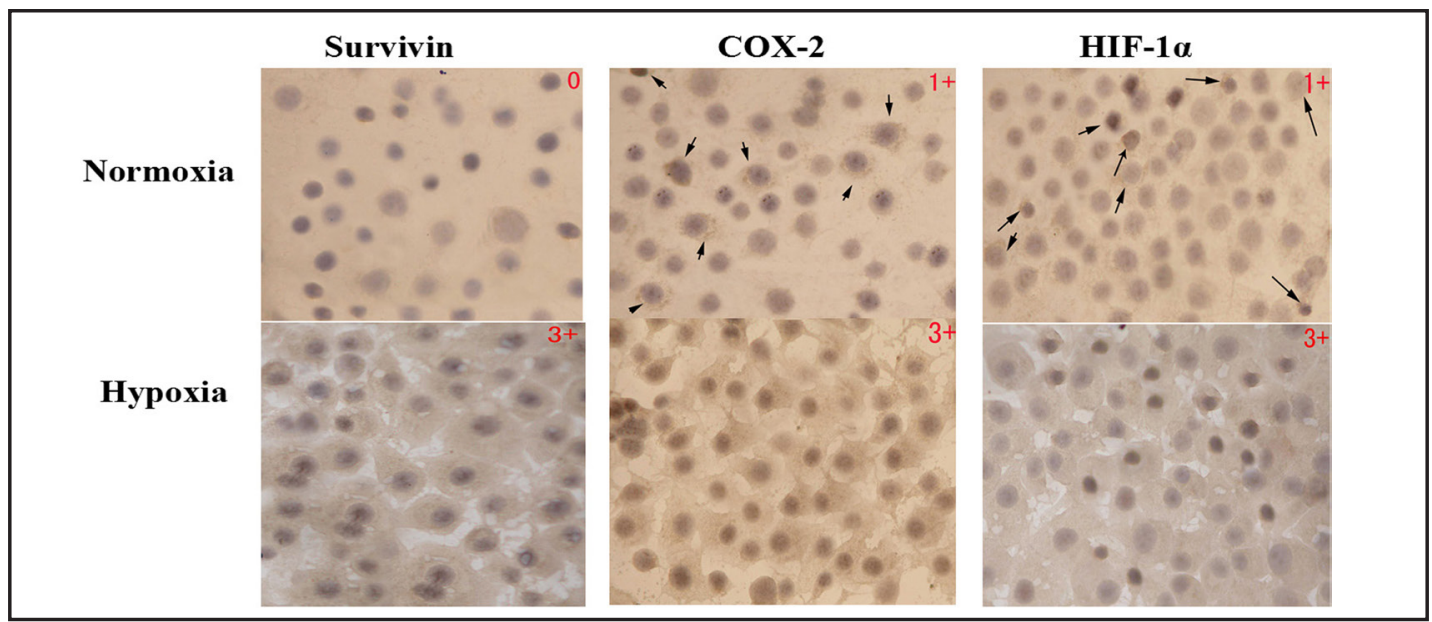

Fig. 1. Cox-2, HIF-1 $\alpha$ and survivin expression in HUVECs in the presence or absence of hypoxic conditions by immunohistochemistry. Elevated Cox-2, HIF-1 $\alpha$ and survivin expression after hypoxic treatment for 24 hrs compared to those under normal conditions. 0 , no labeling; $1+$, mild labeling $(<30 \%$ positive cells, arrow); $2+$, moderate labeling (30-70\% positive cells); and $3+$, intense labeling ( $>70 \%$ positive cells).

Fig. 2. The effect of celecoxib on the growth of HUVECs under normoxic or hypoxic conditions for 24 hrs using an MTT assay. Cells were cultured in 96well plates at a concentration of $5 \times 10^{3} /$ well. Cells were treated with celecoxib $(15,30,65,100 \mu \mathrm{M})$. The proliferation of HUVECs following 30,65, and 100 $\mu \mathrm{M}$ celecoxib treatment was significantly reduced compared to after $15 \mu \mathrm{M}$ celecoxib treatment. The proliferation under hypoxic conditions was significantly lower than that under normoxic conditions following $65 \mu \mathrm{M}$ celecoxib treatment $\left({ }^{*} \mathrm{P}<0.01\right)$.

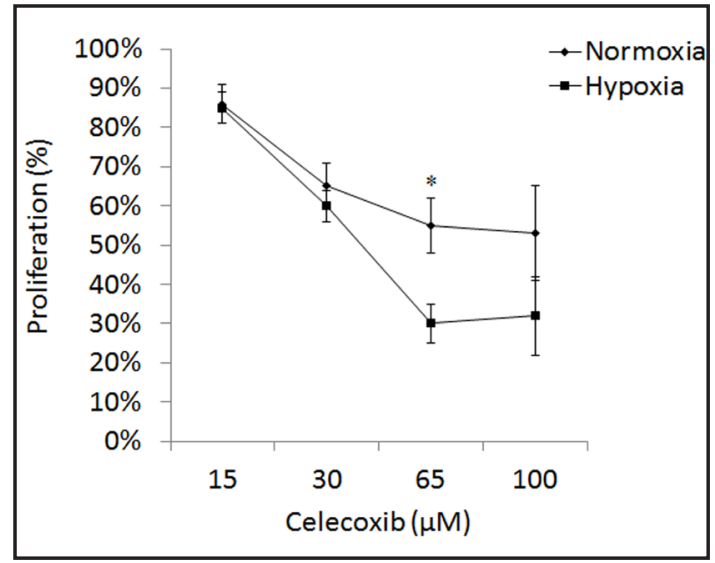




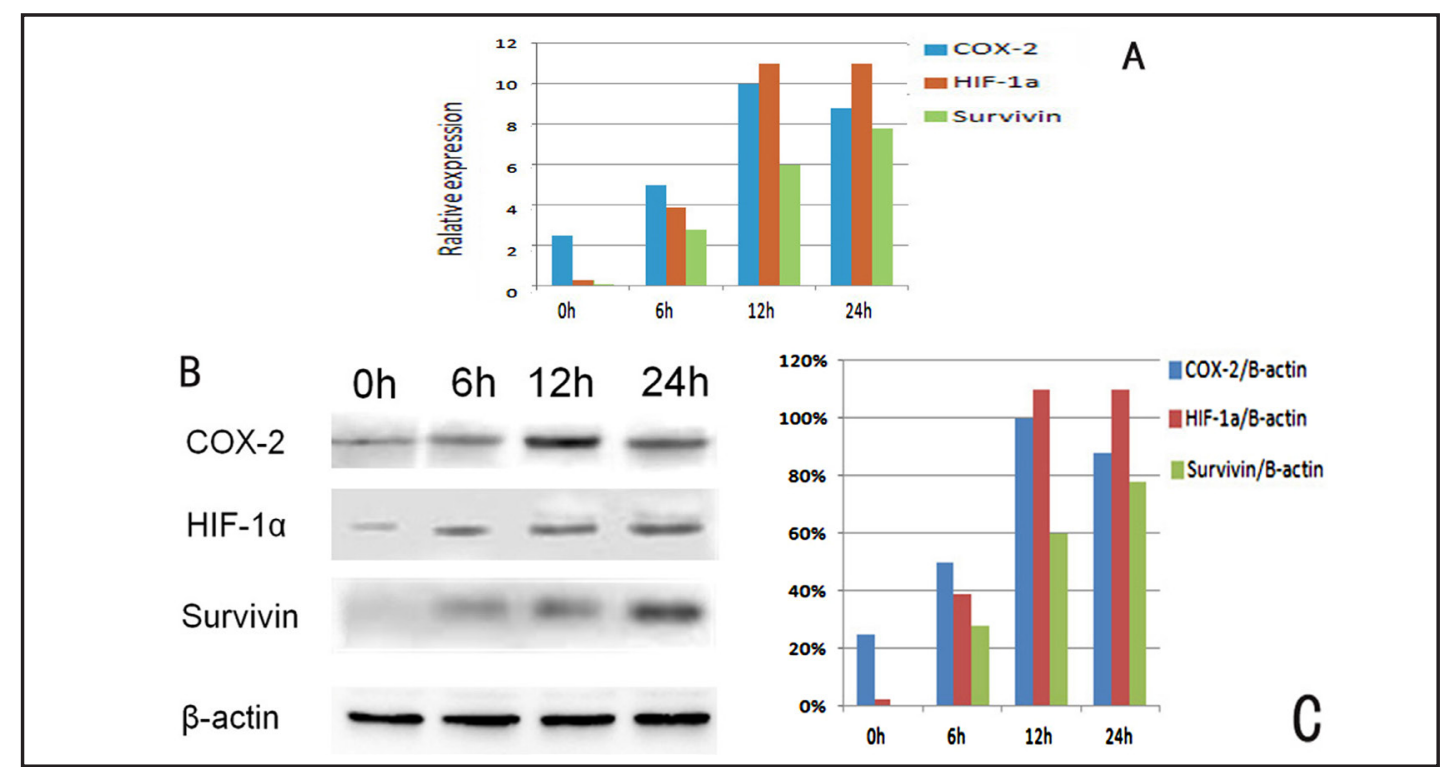

Fig. 3. Quantitative analysis of expression of HIF- $1 \alpha$, Cox- 2 and survivin by real-time PCR and Western blotting in hypoxic HUVECs. (A) Total RNA was extracted and detected by real-time PCR after hypoxia at different time points. The levels of $\beta$-actin show equal protein loading of the samples (loading control). (B) Western blot showed protein expression levels of HIF-1 $\alpha$, Cox-2 and survivin. (C) Statistical analysis of HIF-1 $\alpha$, Cox- 2 and survivin expression in hypoxic HUVECs. The densities of HIF- $1 \alpha$, Cox- 2 and survivin were normalized against the $\beta$-actin signal.

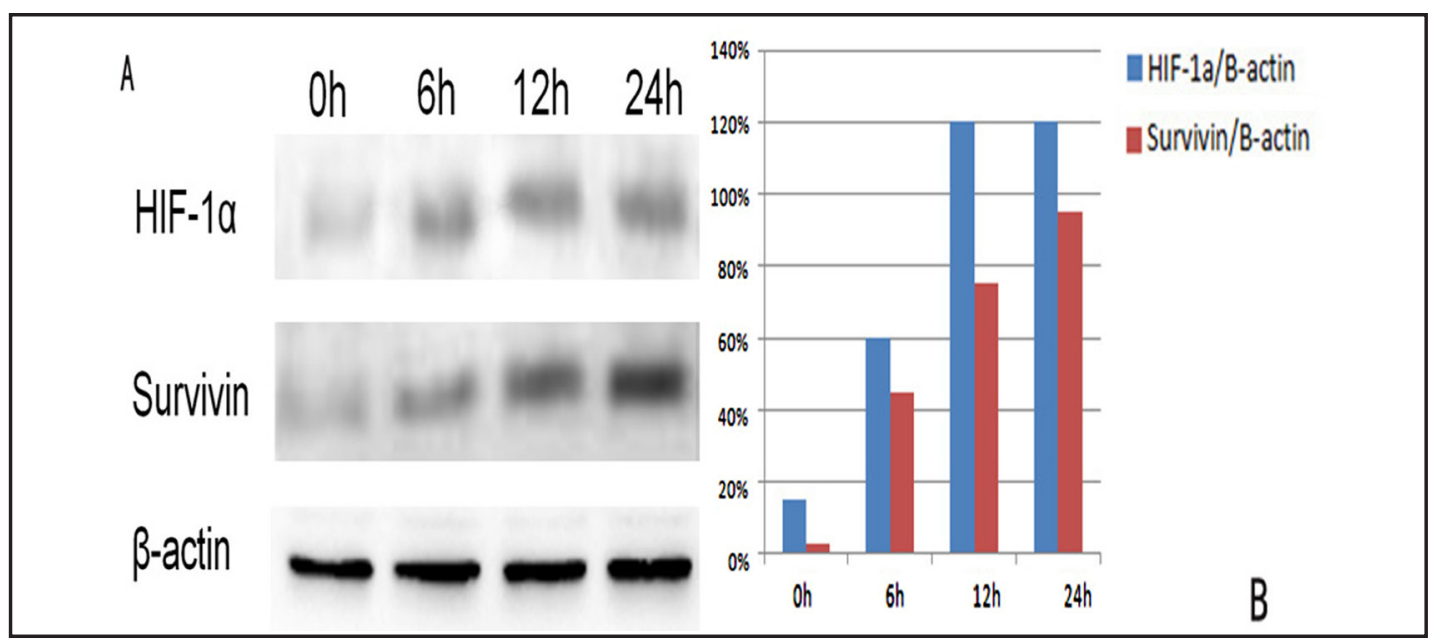

Fig. 4. HIF- $1 \alpha$ and survivin protein levels in $\mathrm{CoCl}_{2}$-treated HUVECs. A hypoxic environment was created using $125 \mu \mathrm{M} \mathrm{CoCl}_{2}$ to examine if HIF-1 $\alpha$ accumulation was directly involved in hypoxia-induced survivin up-regulation. Cells were treated with $125 \mu \mathrm{M} \mathrm{CoCl}_{2}$ for $0,6,12,24 \mathrm{hrs}$, and the protein levels of HIF-1 $\alpha$ and survivin were detected by Western blotting. The levels of $\beta$-actin served as a loading control. All of the results were quantitated and normalized against $\beta$-actin measurements.

Up-regulation of survivin expression induced by $\mathrm{CoCl} 2$

As shown in Fig. 4A \& 4B, CoCl2 induced both HIF-1 $\alpha$ and survivin expression, showing a similar pattern to that induced by hypoxia. These findings demonstrate that $\mathrm{CoCl} 2$ chemically induced hypoxia may up-regulate survivin expression in HUVECs, and HIF-1 $\alpha$ overexpression alone could stimulate survivin expression.

\section{KARGER}


Fig. 5. Effects of genistein on HIF-1 $\alpha$ and survivin expression in HUVECs under normoxic or hypoxic conditions. Genistein was used to block HIF-1 $\alpha$ expression. HUVECs were cultured for 24 hrs under hypoxic conditions in the presence of 0,50 , 100 , or $200 \mu \mathrm{M}$ genistein and pre-incubated for 30 mins before exposure to hypoxia. The cells were collected, and the expression of HIF-1 $\alpha$ and survivin were determined by Western blotting. $\beta$-actin levels served as a loading control. All of the results were quantitated and normalized against $\beta$-actin measurements.

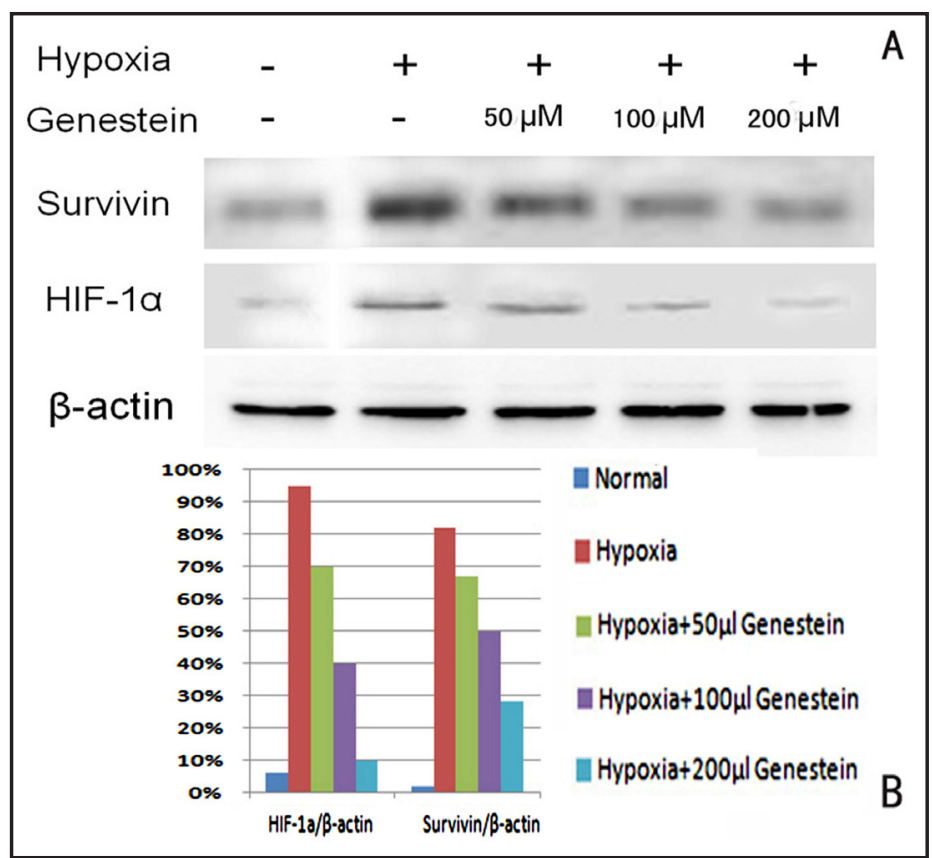

Fig. 6. Effects of celecoxib and $\mathrm{PGE}_{2}$ on Cox-2 and survivin expression in HUVECs under normoxic and hypoxic conditions. To test the concentration-dependent effect of celecoxib on the expression of hypoxia-induced survivin, different concentrations $(15,30,65$, $100 \mu \mathrm{M}$ ) of celecoxib were added to HUVEC medium 4 hrs before hypoxic treatment. To test the effect of exogenous $\mathrm{PGE}_{2}$ on hypoxia-induced survivin expression in the presence of celecoxib, $5 \mu \mathrm{M} \mathrm{PGE}_{2}$ was introduced to HUVEC culture media exposed to hypoxia for $24 \mathrm{hrs}$ in the presence of $65 \mu \mathrm{M}$ celecoxib. The cells

were collected to assay survivin and Cox- 2 levels by Western blotting. $\beta$-actin levels served as a loading control, and the relative expression levels of Cox- 2 and survivin were normalized to $\beta$-actin.

\section{Inhibition of hypoxia-induced survivin expression by genistein}

We used genistein to block the pathway of HIF-1 $\alpha$ induced gene expression. As shown in Fig. 5A \& 5B, compared with vehicle treatment, HIF-1 $\alpha$ expression was significantly reduced in the presence of 50,100 or $200 \mu \mathrm{M}$ genistein under hypoxic conditions for 24 hrs. The dose-dependent inhibitory effects of genistein on hypoxia-induced survivin expression were shown in the following order: $200 \mu \mathrm{M}>100 \mu \mathrm{M}>50 \mu \mathrm{M}$. Genistein, however, was unable to fully compensate for the increased survivin expression because it was still positive in the presence of $200 \mu \mathrm{M}$ genistein.

\section{KARGER}


Fig. 7. $\mathrm{PGE}_{2}$ protein concentrations in the medium, as analyzed by ELISA assay. HUVECs exposed to normoxia, hypoxia alone or hypoxia plus $65 \mu \mathrm{M}$ celecoxib for 24 hrs were collected for the analysis.

Up-regulation of hypoxia-induced survivin was suppressed by celecoxib

Treatment with increasing doses of celecoxib (15-100 $\mu \mathrm{M})$ in HUVECs under hypoxic conditions for 24 hrs significantly reduced the protein expression of Cox- 2 and survivin in a dose-dependent manner. Celecoxib (15

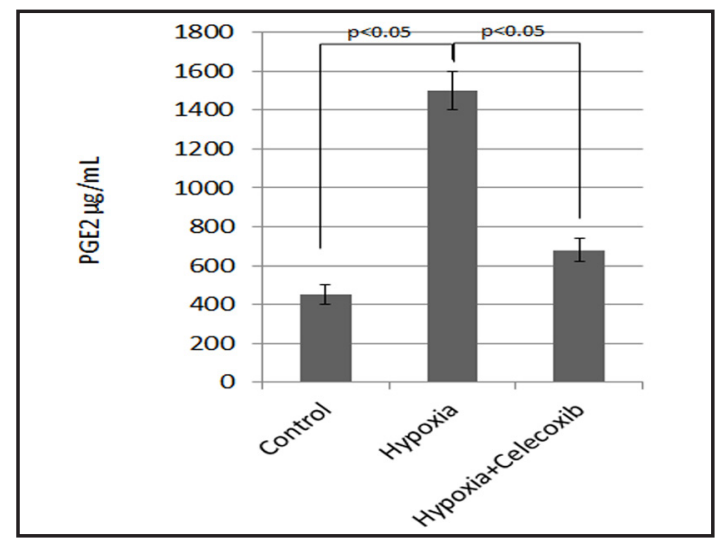
$\mu \mathrm{M})$ partially diminished hypoxia-induced Cox-2 expression, as did $30 \mu \mathrm{M}$ celecoxib, while $65 \mu \mathrm{M}$ celecoxib almost completely abolished elevated Cox- 2 and survivin expression. PGE $_{2}$ partially reversed the inhibitory effect of celecoxib on hypoxia-induced survivin expression, while reduced Cox- 2 expression by celecoxib also underwent simultaneous reversal (Fig. 6A \& 6B).

Effects of hypoxia and celecoxib on $P G E_{2}$ activation

$\mathrm{PGE}_{2}$ production in HUVECs exposed to hypoxia for $24 \mathrm{hrs}$ increased compared to the control $(\mathrm{p}<0.05)$. Compared with hypoxia treatment alone, celecoxib reduced $\mathrm{PGE}_{2}$ expression $(p<0.05)$ (Fig. 7).

\section{Discussion}

HIF is the key regulator of oxygen homeostasis [29]. In our study, approximately 24 hrs after hypoxic treatment, HIF-1 $\alpha$ protein was predominantly expressed in the nucleus and neoplasm, consistent with the theory that HIF- $1 \alpha$ tends to be stabilized as a result of hypoxia-induced inhibition of PHD and FIH activities and then translocates to the nucleus [30]. In addition, HIF- $1 \alpha$ regulation mainly occurs at the post-translational level and is related to changes in oxygen tension. By blocking HIF- $1 \alpha$ degradation, $\mathrm{CoCl}_{2}$ produces an in vitro hypoxic environment, comparable to that created by in vivo hypoxia [31]. Our study demonstrated that $\mathrm{CoCl}_{2}$ and hypoxia-induced HIF-1 $\alpha$ accumulation could stimulate survivin expression in ECs in a time-dependent manner; under both treatments, HIF-1 $\alpha$ protein expression was time-dependent, whereas its mRNA expression remained stable, in line with the findings by a recent review on hypoxia [32]. Meanwhile, hypoxia is a major stimulator of Cox- 2 expression resulting from HIF- $1 \alpha$ binding to a hypoxia response element within the Cox-2 promoter interacting with HIF-1 $\alpha$ [33]. Hypoxia-regulated Cox- 2 and HIF- $1 \alpha$ expression play critical roles in pathological neovascularization [34]. Expression of HIF-1 $\alpha$, Cox-2 and survivin were up-regulated by hypoxia at both the gene and protein levels in ECs in our study.

Cox-2 is associated with inflammation, angiogenesis, proliferation and tumor growth. The mechanism of its hypoxia-induced pathway, however, is still poorly understood. As a selective Cox- 2 inhibitor, celecoxib has been accepted by the Food and Drug Administration (FDA) as a potent antiangiogenic and antitumor activity drug in the treatment of human cancer [35]. We found that the up-regulation of Cox-2 and survivin was induced by hypoxia, with elevated mRNA and protein expression of survivin occurring after Cox- 2 induction. Additionally, hypoxia-induced survivin expression was reduced in the presence of $30 \mu \mathrm{M}$ celecoxib, compared to that in the presence of $15 \mu \mathrm{M}$ celecoxib, indicating hypoxia-induced survivin is a downstream gene of Cox-2 in HUVECs. These findings are consistent with other studies that suggest survivin and Cox-2 are often co-expressed in many cancers [36].

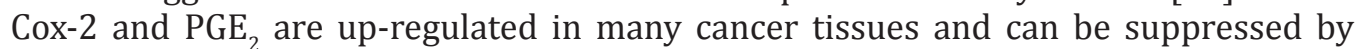
Cox-2 inhibitors [37]. The present study found that expression of $\mathrm{PGE}_{2}$ and Cox-2 were 
elevated simultaneously under hypoxia. The findings that celecoxib dramatically reduced $\mathrm{PGE}_{2}$ production and $\mathrm{PGE}_{2}$ partially blocked the inhibitory effect of celecoxib on hypoxiainduced survivin expression suggest that $\mathrm{PGE}_{2}$ may be a mediator of Cox-2-induced survivin up-regulation. It is well established that $\mathrm{Cox}_{-} 2 / \mathrm{PGE}_{2}$ stimulates VEGF expression through the HIF-1 $\alpha$ pathway and contributes to tumor angiogenesis [38]. $\mathrm{PGE}_{2}$ also induces HIF-1 $\alpha$ stabilization and nuclear localization in a human prostate cancer cell line [39]. These findings propose that Cox- 2 and $\mathrm{PGE}_{2}$ might promote survivin expression by indirectly modifying the HIF-1 $\alpha$ pathway. On the other hand, hypoxia-induced survivin expression is preserved by the sustained rise of Cox-2 expression and $\mathrm{PGE}_{2}$ production in HUVECs exposed to hypoxia, suggesting that Cox-2 may be a potential mediator for hypoxia-induced survivin expression. Hypoxia-driven survivin expression in cancer cells is also reliant on the Cox-2 pathway [40].

It has been found that blocking the HIF-1 $\alpha$ pathway by inhibitors such as genistein $[41,42]$ and YC-1 $[43,44]$ results in the down-regulation of survivin expression in tumor cells, diminishing angiogenesis and tumor growth. Genistein exhibited a similar effect in the present study, in which HIF-1 $\alpha$-mediated survivin expression under hypoxic conditions and HIF-1 $\alpha$ inhibition by genistein in HUVECs led to reduced rather than completely diminished survivin expression, even in the presence of $200 \mu \mathrm{M}$ of genistein, implying that hypoxiainduced survivin expression can be initiated through other molecular pathways besides HIF- $1 \alpha$. To the best of our knowledge, this is the first study that shows survivin expression can be stimulated by hypoxia and $\mathrm{CoCl} 2$-induced HIF-1 $\alpha$ accumulation in HUVECs in a time-dependent manner, although other studies have found hypoxia up-regulates survivin expression in cancer cell lines [45].

We propose that hypoxia-induced survivin expression is regulated through dual interdependent mechanisms directly involving HIF-1 $\alpha$ and indirectly involving the Cox-2/ $\mathrm{PGE}_{2}$ pathways in HUVECs. Accordingly, celecoxib may have inhibited survivin expression through blocking the Cox-2/PGE 2 pathway. Although the apoptosis pathways for survivin regulation were not investigated in our study, it still could be assumed that Cox- 2 suppression by celecoxib plays important roles in inhibiting hypoxia-induced survivin expression. Other transcription factors may also be involved in hypoxia-induced survivin expression and therefore warrant further investigation.

In conclusion, for the first time, our study observed that hypoxia-induced survivin expression in HUVECs may be mediated through dual interdependent mechanisms directly involving HIF- $1 \alpha$ and indirectly involving the Cox-2/PGE 2 pathways, and celecoxib may offset hypoxia-induced survivin expression. The findings propose the potentially therapeutic value of celecoxib in the treatment of pathologic ocular vascular disease.

\section{Acknowledgements}

This study was supported by the Doctor Science Foundation of Liaoning Province, China (No. 20091115).

\section{Disclosure Statement}

All authors declared no conflict of interest.

\section{References}

1 Köhn C, Dubrovska G, Huang Y, Gollasch M: Potent regulator of vascular tone and stimulator of angiogenesis. Int J Biomed Sci 2012;8:81-86.

2 Heo K, Kim YH, Sung HJ, Li HY, Yoo CW, Kim JY, Park JY, Lee UL, Nam BH, Kim EO, Kim SY, Lee SH, Park JB, Choi SW: Hypoxia-induced up-regulation of apelin is associated with a poor prognosis in oral squamous cell carcinoma patients. Oral Oncol 2012;48:500-506.

3 Chang MX, Ma YP: Effect of flumatinib mesylate on C-MYC, HIF-1 $\alpha$ and VEGF in U226 line. Zhongguo Shi Yan Xue Ye Xue Za Zhi 2013;21:1496-1500. 
4 Lei Lv, Yuan JD, Tao H, Zhang CH, Zhu ZN, Wang L, Jiang GS, Zeng FQ: Stabilization of Snail by HIF-1 $\alpha$ and TNF- $\alpha$ is required for hypoxia-induced invasion in prostate cancer PC3 cells. Molecular Biology Reports 2014;41: 4573-4582.

5 Zhang B, Yin CP, Zhao Q Yue SW: Upregulation of HIF-1 $\alpha$ by hypoxia protect neuroblastoma cells from apoptosis by promotingsurvivin expression. Asian Pac J Cancer Prev 2014;15:8251-8257.

6 Doucette T, Latha K, Yang Y, Fuller GN, Rao A, Rao G: Survivin transcript variant 2 drives angiogenesis and malignant progression in proneuralgliomas. Neuro Oncol 2014;16:1220-1228.

7 Chen P, Zhu J, Liu DY, Li HY, Xu N, Hou M: Over-expression of survivin and VEGF in small-cell lung cancer may predict the poorerprognosis.Med Oncol 2014;31:775-782.

8 Li DW, Zhou L, Jin B, Xie J, Dong P: Expression and significance of hypoxia-inducible factor- $1 \alpha$ and survivin in laryngeal carcinoma tissue and cells. Otolaryngol Head Neck Surg 2013;148:75-81.

9 Bai H, Ge S, Lu J, Qian G, Xu R: Hypoxia inducible factor-1 $\alpha$-mediated activation of survivin in cervical cancer cells. J Obstet Gynaecol Res 2013;39:555-563.

10 Liu NN, Sun YZ, Zhao N, Chen L: Role of hypoxia-inducible factor - $1 \alpha$ and survivn in oxygen-induced retinopathy in mice. Int J Clin Exp Pathol 2014;7: 6814-6819.

11 Harper J, Sainson RC: Regulation of the anti-tunour immune response by cancer-associated fibroblasts. Semin Cancer Biol 2014;25:69-77.

12 Bai XM, Jiang H, Ding JX, Peng T, Ma J, Wang YH, Zhang L, Zhang H, Leng J: Prostaglandin E2 upregulates survivin expression via the EP1 receptor in hepatocellular carcinoma cells. Life Sci 2010;86:214-223.

13 Liu NN, Sun YZ, Zhao N, Chen L: Rofecoxib inhibits retinal neovascularization via down regulation of cyclooxygenase- 2 and vascular endothelial growth factor expression. Clin Experiment Ophthalmol 2015;43:458-465.

14 Wang HW, Lo HH, Chiu YL, Chang SJ, Huang PH, Liao KH, Tasi CF, Wu CH, Tsai TN, Cheng CC, Cheng SM: Dysregulated miR-361-5p/VEGF Axis in the Plasma and Endothelial Progenitor Cells of Patients with Coronary Artery Disease. PLoS One 2014;9:e98070.

15 Wang AH, Tian XY, Yu JJ, Mi JQ Liu H, Wang RF: Celecoxib radiosensitizes the human cervical cancer HeLa cell line via a mechanism dependent on reduced cyclo-oxygenase- 2 and vascular endothelial growth factor C expression. J Int Med Res 2012;40:56-66.

16 Chen QJ, Zhang MZ, Wang LX: Gensenoside Rg3 inhibits hypoxia-induced VEGF expression in human cancer cells. Cell Physiol Biochem 2010;26:849-858.

17 Baratelli F, Krysan K, Heuzé-Vourc'h N, Zhu L, Escuadro B, Sharma S, Reckamp K, Dohadwala M, Dubinett SM: PGE2 confers survivin-dependent apoptosis resistance in human monocyte-derived dendritic cells. J Leukoc Biol 2005;78:555-564.

18 Chen J, Li T, Liu Q, Jiao H, Yang W, Liu X, Huo Z: Clinical and prognostic significance of HIF-1 $\alpha$, PTEN, CD44v6, and survivin for gastric cancer: a meta-analysis. PLoS One 2014;9:e91842.

19 Fernando W, Rupasinghe HP, Hoskin DW: Regulation of Hypoxia-inducible Factor-1 $\alpha$ and Vascular Endothelial Growth Factor Signaling by Plant Flavonoids. Mini Rev Med Chem 2015;15:479-489.

20 Zhou J, Liu Y: Effects of genistein and estrogen on the genioglossus in rats exposed to chronic intermittent hypoxia may be HIF-1 $\alpha$ dependent. Oral Dis 2013;19:702-711.

21 Büchler P, Reber HA, Büchler MW, Friess H, Lavey RS, Hines OJ: Antiangiogenic activity of genistein in pancreatic carcinoma cells is mediated by the inhibition of hypoxia-inducible factor-1 and the downregulation of VEGF gene expression.Cancer 2004;100:201-210.

22 Chae IG, Kim DH, Kundu J, Jeong CH, Kundu JK, Chun KS: Generation of ROS by CAY10598 leads to inactivation of STAT3 signaling and induction ofapoptosis in human colon cancer HCT116 cells. Free Radic Res 2014;48:1311-1321.

23 Misra S, Sharma K: COX-2 signaling and cancer: new players in old arena. Curr Drug Targets 2014;15:347359.

24 Mobahat M, Narendran A, Riabowol K: Survivin as a preferential target for cancer therapy.Int J Mol Sci 2014;15:2494-2516.

25 Yang Y, Zhu J, Gou H, Cao D, Jiang M, Hou M: Clinical significance of Cox-2, Survivin and Bcl-2 expression in hepatocellular carcinoma (HCC). Med Oncol 2011;28:796-803.

26 Duan DP, Dang XQ, Wang KZ, Wang YP, Zhang H, You WL: The cyclooxygenase-2 inhibitor NS-398 inhibits proliferation and induces apoptosis in humanosteosarcoma cells via downregulation of the survivin pathway. Oncol Rep 2012;28:1693-1700. 
27 Singh P, Hoggatt J, Hu P, Speth JM, Fukuda S, Breyer RM, Pelus LM : Blockade of prostaglandin E2 signaling through EP1 and EP3 receptors attenuats Flt3L-dependent dendritic cell development from hematopoietic progenitor cells. Blood 2012;119:1671-1682.

28 Lin J, Hsiao PW, Chiu TH, Chao J: Combination of cyclooxygenase-2 inhibitors and oxaliplatin increases the growth inhibition and death in human colon cancer cells. Biochem Pharmacol 2005;70:658-667.

29 Bruning U, Fitzpatrick SF, Frank T, Birtwistle M, Taylor CT, Cheong A: NFкB and HIF display synergistic behaviour during hypoxic inflammation. Cell Mol Life Sci 2012;69:1319-1329.

30 Ivan M, Kondo K, Yang H, Kim W, Valiando J, Ohh M, Salic A, Asara JM, Lane WS, Kaelin WG Jr: HIFalpha targeted for VHL-mediated destruction by proline hydroxylation: implications for 02 sensing. Science 2001;292:464-468.

31 Liu XH, Kirschenbaum A, Yao S, Stearns ME, Holland JF, Claffey K, Levine AC: Upregulation of vascular endothelial growth factor by cobalt chloride-simulated hypoxia is mediated by persistent induction of cyclooxygenase-2 in a metastatic human prostate cancer cell line. Clin. Exp Metastas 1999;17:687-694.

32 Maxwell PH, Ratcliffe PJ: Oxygen sensors and angiogenesis. Semin Cell Dev Biol 2002;13:29-37.

33 Csiki I, Yanagisawa K, Haruki N, Nadaf S, Morrow JD, Johnson DH, Carbone DP: Thioredoxin-1 modulates transcription of cyclooxygenase-2 via hypoxia-inducible factor-1alpha in non-small cell lung cancer. Cancer Res 2006;66:143-150.

34 Weidemann A, Krohne TU, Aguilar E, Kurihara T, Takeda N, Dorrell MI, Simon MC, Haase VH, Friedlander M, Johnson RS: Astrocyte hypoxic response is essential for pathological but not developmental angiogenesis of the retina. Glia 2010;58:1177-1185.

35 Ninomiya I, Nagai N, Oyama K, Hayashi H, Tajima H, Kitagawa H, Fushida S, Fujimura T, Ohta T: Antitumor and anti-metastatic effects of cyclooxygenase- 2 inhibition by celecoxib on human colorectal carcinoma xenografts in nude mouse rectum. Oncol Rep 2012;28:777-784.

36 Fan L, Sun G, Ma T, Zhong F, Wei W: Melatonin overcomes apoptosis resistance in human hepatocellular carcinoma by targeting survivin and XIAP. J Pineal Res 2013;55:174-183.

37 Hasegawa K, Ishikawa K, Kawai S, Torii Y, Kawamura K, Kato R, Tsukada K, Udagawa Y: Overcoming paclitaxel resistance in uterine endometrial cancer using a COX-2 inhibitor. Oncol Rep 2013;30:2937-2944.

38 Huang SP, Wu MS, Shun CT, Wang HP, Hsieh CY, Kuo ML, Lin JT: Cyclooxygenase-2 increases hypoxiainducible factor-1 and vascular endothelial growth factor to promote angiogenesis in gastric carcinoma. Journal of Biomedical Science 2005;12:229-241.

39 Liu XH, Kirschenbaum A, Lu M, Yao S, Dosoretz A, Holland JF, Levine AC: Prostaglandin E2 induces hypoxiainducible factor-1alpha stabilization and nuclear localization in a human prostate cancer cell line. J Biol Chem 2002;277:50081-50086.

40 Saxena A, Shoeb M, Tammali R, Ramana KV, Srivastava SK: Aldose reductase inhibition suppresses azoxymethane-induced colonic premalignant lesions in C57BL/KsJ-db/dbmice. Cancer Lett 2014;355:141147.

41 Song M, Tian X, Lu M, Zhang X, Ma K, Lv Z, Wang Z, Hu Y, Xun C, Zhang Z, Wang S: Genistein exerts growth inhibition on human osteosarcoma MG-63 cells via PPAR $\gamma$ pathway. Int J Oncol 2015;46:1131-1140.

42 Lepri SR, Zanelatto LC, da Silva PB, Sartori D, Ribeiro LR, Mantovani MS: Effects of genistein and daidzein on cell proliferation kinetics in HT29 colon cancer cells: the expression of CTNNBIP1 ( $\beta$-catenin), APC (adenomatous polyposis coli) and BIRC5 (survivin). Hum Cell 2014;27:78-84.

43 Hsia TC, Liu WH, Qiu WW, Luo J, Yin MC: Maslinic acid induces mitochondrial apoptosis and suppresses HIF-1 $\alpha$ expression in A549 lung cancer cells under normoxic and hypoxic conditions. Molecules 2014;19:19892-19906.

44 Lee CS, Kwak SW, Kim YJ, Lee SA, Park ES, Myung SC, Kim W, Lee MS, Lee JJ: Guanylate cyclase activator YC-1 potentiates apoptotic effect of licochalcone A on human epithelial ovarian carcinoma cells via activation of death receptor and mitochondrial pathways. Eur J Pharmacol 2012;683:54-62.

45 Sun XP, Dong X, Lin L, Jiang X, Wei Z, Zhai B, Sun B, Zhang Q, Wang X, Jiang H, Krissansen GW, Qiao H, Sun $\mathrm{X}$ : Up-regulation of survivin by AKT and hypoxia-inducible factor $1 \alpha$ contributes to cisplatin resistance in gastriccancer. FEBS J 2014;281:115-128. 